UDC 811.134.2'42

DOI https://doi.org/10.32838/2663-6069/2020.2-1/30

Popova N. M.

Taras Shevchenko National University of Kyiv

\title{
LINGOCULTURAL SPECIFICITY OF INDEPENDENCE CONCEPT IN THE UKRAINIAN AND SPANISH LANGUAGE WORLDVIEWS
}

The article is devoted to the study of linguocultural peculiarities of the INDEPENDENCE concept in the modern language worldviews of Ukraine and Spain. Due to such linguistic methods as semantic and cognitive analysis, taking into account the methods of such related disciplines as cultural studies, sociology and psychology, applying the method of full field enumeration sampling, the means of concept's verbalization in both language worldviews as well as common and distinctive features of concept's nuclear element and cognitive characteristics were identified. Having used the obtained data, we managed to compare the conceptual, associative and axiological constituents of the investigated mental units in both worldviews. The analysis of the interpretation field has allowed revealing differences in Spaniards' and Ukrainians' concept perception, caused by different worldviews, mentalities, historical, cultural, social and political factors, as well as variations in these nations' language consciousness.

It has been determined that the INDEPENDENCE concept has acquired specific features in Ukrainian and Spanish language cultures due to the great influence of extralinguistic factors. This fact is particularly evident in the distinct connotations of concept's verbalizers. Thus, the nuclear element of the Spanish INDEPENDENCE concept is characterized by a more personal nature, focusing on the individual and it is less subjected to globalized society's external influence, whereas in modern Ukrainian language culture it is mostly focused on a common national wealth and on Ukraine's position in the modern world. Negative cognitive features representation of the investigated concept in the Spanish worldview is based on lexemes having a common basis with the concept's verbalizer (independencia -independentismo), whereas in the Ukrainian language worldview the words незалежність and сепаратизм are antonyms.

Key words: culturally tagged concept, conceptual sphere, language worldviews, notional constituent, associative constituent, axiological constituent, connotation.

Introduction. Various differences in national worldviews are able to provoke misunderstanding in intercultural communication. Despite the opinion that the concepts existing in different cultures can't be recognized as nationally tagged mental units, they change their universal features converting into culturally and socially determined concepts. Such differences were treated in scientific papers of A. Agibalova, C. Goddard, I. Holubovska, V. Karasyk, N. Med, A. Mussolff, $\mathrm{S}$. Vorkachov and other linguists. Combining linguistic and cultural approach to the language study within cognitive linguistics methods has gained popularity in Eastern Europe and developed practically into a separate direction of cognitive linguistics - cognitive linguoculturology. This new approach differs from the linguocognitive conception by adding culturally specific features of peoples' thinking embedded in the national conceptual sphere and reflected in the language world view to the dichotomy "language mentality".

According to A. Balashova, the cognitive linguocultural approach examines the specifics of the national conceptual sphere from "culture to language", since the concepts contain rational, emotional and evaluative characteristics and, accordingly, they are culturally significant for particular people [1, c. 43]. This approach determines the concept as a basic cultural unit containing a notional, associative and value components, being dominated the last one.

The universal INDEPENDENCE concept, which is an importance basis for contemporary linguistic worldview, has been developing in Ukrainian and Spanish conceptual spheres for many centuries. It has been influenced by different types of consciousness, such as philosophical, religious, political, house holding, etcetera [6, c. 164], deriving from the universality and involving special ethnic and cultural components in its notion and value structure. This part of national Ukrainian and Spanish conceptual spheres has been actualized lately due to such event as the movement for independence in Catalonia in Spain and the annexation of Crimea and the war in the east of Ukraine.

The relevance of our research is determined by humanity scientists' deep interest in reveling 
the most effective methods of collaboration among different countries and depressing different conflicts which could ruin the world. Meanwhile cognitive linguists, explaining differences among culturallytagged concepts which have the same origin and are characterized by universal features, are trying to realize how human's consciousness and language interact. As the usage of language is the most relevant reflecting of conceptual sphere, the cognitive analysis of INDEPENDENCE concept in Ukrainian and Spanish worldviews allows comparing them and determining the most striking cultural differences of its notional and value constituents.

The aim of the scientific paper is to reveal differences in the investigated concept's elements in Ukrainian and Spanish worldviews, explaining their proceedings and facilitating translation process in order to eliminate misunderstanding between representations of Ukrainian and Spanish nations. Having been determined means of verbalization of INDEPENDENCE concept and its conceptual features in both languages, the comparative method gives us a possibility to compare universal and nationally-tagged elements of concept's nuclear and periphery field.

Thus, our research object is INDEPENDENCE concept in Ukrainian and Spanish conceptual spheres, while the subject is its notional, associative and value component and its differences revealed in Ukrainian and Spanish language worldviews.

Methodology. The methodology of the investigation is based on the combination of cognitive and comparative linguistics methods altogether with method used in culturological studies, sociology and psychology. The quantitative analysis helps to select the most frequent language means of concept's verbalization. The semantic analysis allows to determine the lexicographic (encyclopedic) and psycholinguistic (sensory) content of language units which verbalize the concept. The cognitive interpretation of the semantic research results makes it possible to draw conclusions about mental entities by engaging cultural, historical and everyday information and is carried out by analyzing the interpretative field of the concept reflecting the attitude of a certain conceptual sphere representatives to concept's information and value content which is formed by the set of its cognitive features and turns into a certain type of knowledge, subjected to logical thinking and cognition operations in human's mind. The comparative analysis of obtained results reveals specific nationally tagged features, permitting to realize Ukrainians' and Spaniards' comprehension and acceptance of the same concept and prove the fact that even universal concepts, appropriate to all nations in the world, can convert into culturally determined mental units having been transformed under certain circumstances and in an authentic cultural and social environment.

Journalistic articles, radio and TV comments and oratory essays related to present-day social and political situation in both countries have been chosen as an empirical basis for our research from Ukrainian and Spanish mass media, in order to apply contextual and interpretation analysis for revealing conceptual features in Ukrainian and Spanish lexicons, were used to determine the content of language units which verbalize INDEPENDENCE concept.

Results and discussion. The nominative field of the concept consisting of all possible forms of verbalization of its nuclear categories and conceptual features in the language worldview includes semantic, idiomatical, figurativelyassociative and paradigmatic groups [5, c. 112]. While analyzing dictionary definitions, we learned that the nuclear words-verbalizers of the Ukrainian concept HЕЗАЛЕЖНІСТЬ and Spanish concept INDEPENDENCIA are practically corresponding words in this couple of languages. INDEPENDENCIA for Spaniards can be verbalized by the words cualidad (quality), condición (condition), libertad (freedom), entereza (fortitude), firmeza de carácter (strength of character) [15], meanwhile for Ukrainians the most relevant words are воля (freedom of will), свобода (freedom of expression), самостійність (autonomy) [14]. The only difference in concept's notional component of the concept is that the modern Spanish concept's prototype is more personalized; meanwhile Ukrainian one is focused on general social values. Its significant constituents, such as SUBJECT, SUBJECT'S CHARACTERISTICS, OBJECT and ATTRIBUTE [11, c. 185] are focused on person's individualization in the Spanish society, determining his/her own abilities, needs, wishes, persuasions or faith.

The interpretation of INDEPENDENCE concept is closely related to the type of consciousness. To reveal its real society value and its place in a national conceptual sphere in a certain historical period of time we should pay attention not only to its nuclear components but also to peripheral field consisting of conceptual features which appear in the process of people's interpretation of the concept. Thus, the derivative phrases, which verbalize INDEPENDENCE concept are usually figurative and based on people's associations. Nowadays the associative constituent of the Ukrainian 
INDEPENDENCE concept is verbalized with such words combination as globalization, entrance in the EU, economic development, defense of national interest, Russian intervention, peace, while for Spaniards the most frequent associative relations are based on ethnic differences, local traditions, political manipulation, language, rupture and individualization.

The concept's evaluative constituent in the Spanish worldview is mostly represented by the word independentismo which has been using since Catalonia started pretending for a new independent geopolitical status. Being conceptual synonym to the noun independence, the word independentismo gives quite negative valuation to the political and social movement related to the geopolitical status of country's integral part.

The social and political situation in Spain has extrapolated on two opposite opinions due to strong divergent process inside the country. Being one of the strongest economically, having its own language and cultural habits, possessing historical autonomy due to the current Constitution, Catalonia has felt quite independent from the central authorities, except economical and international political issues. The verbs buscar, manifestar (su voluntad), votar (por la independencia) reveal pacific ways of new geopolitical status obtaining. The Catalan INDEPENDENCE concept is characterized by such features as cultura propia, identidad colectiva, raices auténticos, idioma, tradiciones locales. Ser explotado, reprimido belong to negative Catalan concept's features which appeared in the periods of Primo de Rivera's and Franko's military dictatorial regimes and are still being applied to the economic sphere, being Catalonia a contributor of $20 \%$ of the country's total GDP and obtaining much less reinvestment from the state, especially in the period of the last economic crisis. The negative appreciation of the Catalan politics is expressed by the word independentismo catalán, appropriating conflict appearance to some political circles, but not to the desire of population majority as only a third part of Catalan citizens took part in the referendum.

While the political type of consciousness is presented in the language worldview with country's official political course, contextual, metaphorical and idiomatic language units help the researcher realize everyday consciousness interpretation of the phenomenon and determine valid concept's content in national mind. Among the most frequent language means which characterize the Spanish INDEPENDENCIA concept are contextual synonyms, contextual connotations, metaphors and idioms. The phrases votación simbólica, acto de pura propaganda, proyecto independentista, proceso formal, una ruptura tan traumática express negative Spanish society's attitude to the separation process of Catalonia. The Spanish INDEPENDENCE concept obtains such feature as political manipulation and enriches negatively connotated conceptual features, being associated with pressure within such metaphors as presionar al gobierno central, exacerbar la tensión, silenciar la voz; idioms ganar por un pelo, llevar a cabo el gobierno Catalán and special denominations El camino al 9- $N$, Diada. Positive evaluative features of the concept are associated with estado unido, bienestar social, posibilidades, derechos humanos [16].

In Ukraine, otherwise, people living on the separated territories were forced to live separately from the rest of the country, being persuaded by special tactics of so called "hybrid war" or just being scared by military intervention. They don't have strong ethnic differences. Even the question of language has been declared by the outer enemy as a social problem in order to create a conflict, while most of Ukrainians are bilingual and they have never planted the usage ofUkrainian or Russian language as a mean of judgment on a person. Ukrainians on occupied territories actually became hostages of the situation, refusing moving out from their native places. The situation has influenced greatly on the Ukrainian language worldview in which many associations are verbalized by words with negative (загарбники, військова окупаиія, анексія, захоплення, порушення прав людини, наслідки, ізолячія, санкиіï) and positive semantics (патріотизм, єднання, національні інтереси, моральні иінності). The conceptual features verbalized by these words have approached to the close peripheral field of HЕЗАЛЕЖНІСТЬ concept.

Some neutral words obtained connotations being used within the framework of contemporary political and social situation and being collocated in certain linguistic context: військовослужбовець (serviceman) is used as a contextual synonym to the word захисник (defender) which has a gorgeous positive connotation and transmits Ukrainians appreciation and respect to the soldiers: "Дякуємо нашим військовослужбовиям за звитягу та непохитність у захисті свободи і незалежності України" [14].

New metaphors describing the situation and verbalizing conceptual features have appeared in the Ukrainian worldview: війна за уми i серия людей, загнати в дипломатичну пастку, 
рухатися у завданому коридорі, звинувачують владу у всіх грiхах. It means that the investigated concept possesses a wide associative net, occupying quite central position in it and interpreting the reality according to national values.

Idiomatical units, proverbs, saying and popular author's sayings are characterized by their ability to reflect concept's value element, revealing peoples' feelings and emotions, their attitude to the social phenomena. Thus, the phrase російські «зелені чоловічки» nominate a new social reality on Ukrainian society and express people's negative attitude to it. While ділити икуру невбитого ведмедя describes political ambitions and desire to receive proper benefit from the serious and difficult situation. Дамоклів меч within the linguistic context Мінські домовленості reveals evaluation of international attitude towards Ukrainian-Russian military conflict, intensifying the saying's meaning with the verb нависає: "Напруга Мінського прочесу хоч і вимушено спала, «дамоклів меч» изих домовленостей все одно буде нависати над Україною" [13].

Conclusion. Spaniards' and Ukrainians' worldview differences formed for many centuries due to certain political event, living standards, intellectual and educational development, psychological and emotional characteristics of both mentalities have formed particularities of their contemporary perception and interpretation of INDEPENDENCE concept, cultural and social uniqueness of which is determined by the set of its notional, associative and axiological constituents. Being universal, INDEPENDENCE concept while transforming under authentic historical and cultural circumstances has converted into nationally tagged mental unit which represents and important part of Ukrainian and Spanish conceptual sphere.
Its nuclear and periphery constituents differ, being represented by various language units with different connotations in language worldviews of both societies' representatives. Ukrainian concept's nuclear prototype is less personalized and more subjected to external influence than the Spanish one which contains such characteristics as capacidad de valerse por si mismo, asumir sus responsabilidades, no tolerar ingerencias externas, abastecer sus necesidades sin recurrir a otros.

Concept's associations in the Ukrainian and Spanish conceptual spheres are tightly related to nowadays social and political situation in the countries. In the Ukrainian concept such associations as integration, war, international relations, national interests and democracy have been actualized lately. Spanish strong associations are related to autonomy, manipulation, ethnic tradition, regional language, united country and individual freedom.

The evaluation of independence in both societies is demonstrated in its interpretational field where evaluative component is represented by language units with different connotations. Conceptual features with positive connotation is closer to the nuclear part in the Ukrainian concept, while the Spanish mental unit shares evaluative constituent between independence and independentism perception, the last of which is characterized by negative Spaniards' attitude to the divergent movements inside the country.

The perspectives of this research should be conducted to other culturally tagged concepts to reveal and analyze them in order to determine differences in nations' conceptual worldviews, as well as to find possible methods of their harmonization within interdisciplinary approach.

\section{References:}

1. Балашова Е. Ю. Концепты любовь и ненависть в русском и американском языковых сознаниях : автореф. дис. ... канд. филол. наук. Саратов, 2004. 18 с.

2. Воркачёв С. Г. Счастье как лингвокультурный концепт. Москва, 2004. 236 с.

3. Карасик В. И., Слышкин Г. Г. Базовые характеристики лингвокультурных концептов. Антология кониептов. 2005. Т. 1. С. 13-15.

4. Мед Н. Г. Оценочная картина мира в испанской лексике и фразеологии (на материале испанской разговорной речи) : дис. ... д-ра филол. наук : 10.02.05 / Санкт-Петербургский государственный ун-т. Санкт-Петербург, 2008. 332 с.

5. Попова 3. Д., Стернин И. А. Когнитивная лингвистика. Москва, 2007. 314 с.

6. Попова Н. М. Еволюція національно маркованих концептів у мовній картині світу Іспанії : дис. ... д-ра філол. наук: 10.02.05 / Київський національний університет імені Тараса Шевченка. Київ, 2019.451 с.

7. Agibalova T. M. Language Mind as a Mediator of Culture Interiorization. Science and Education a New Dimension: Philology. 2017. V(35). Issue 125. P. 7-9.

8. Goddard C., Wierzbicka A. Words and Meanings : Lexical Semantics Across Domains, Languages, and Cultures. Oxford, 2014. 314 p. 
9. Holubovska I. American Political Linguoculture in the Mirror of National Values (On the Material of Inaugural Speech of Donald Trump). Odessa linguistic journal. 2018. Issue 11, P. 29-36.

10. Musolff A. Metaphor and Cultural Cognition. Advances in Cultural. Melbourne, 2017. P. 325-344.

11. Tomchakovska Yu. Reconstruction of the esthetic concept of charm in the English and Ukrainian linguistic cultures. Odessa linguistic journal. 2018. Issue 11. P. 184-191.

12. Великий тлумачний словник сучасної української мови. Київ-Ірпінь : Перун, 2005. 1728 с.

13. Радіо «Свобода». URL: https://www.radiosvoboda.org/a/30544810.html (Last accessed: 10.04.2020).

14. Укрінформ: мультимедійна платформа іномовлення України. URL: https://www.ukrinform.ua/ (дата звернення: 12.04.2020).

15. Diccionario de Real Academia Española, 23. ${ }^{\text {a }}$ ed., Madrid: Espasa, 2014. URL: https://dle.rae.es/?w=independencia (Last accessed: 30.03.2020).

16. El País. (2020). URL: www.elpais.es. (Last accessed: 20.04.2020).

\section{ПоПОВа Н. М. ЛІНГВОКУЛЬТУРНА СПЕЦИФІКА КОНЦЕПТУ НЕЗАЛЕЖНІСТЬ В УКРАЇНСЬКІЙ ТА ІСПАНСЬКІЙ МОВНІЙ КАРТИНІ СВІТУ}

Статтю присвячено вивченню лінгвокультурної спещифіки концепту НЕЗАЛЕЖНІСТЬ у сучасній мовній картині світу Украӥни та Іспанії. Завдяки лінгвістичним методам семантико-когнітивного та порівняльного аналізу, з урахуванням методів суміжних дисииплін, таких як культурологія, соиіологія та психологія, методом суцільної вибірки було визначено засоби вербалізації концепту в обох мовних картинах світу, а також спільні й відмінні мовні засоби репрезентації ядерних та периферійних ознак кониепту, що дало змогу порівняти поняттєвий, асоціативний та аксіологічний складники цихх ментальних одиниць. Аналіз інтерпретаційного поля дозволив встановити відмінності у сприйнятті конщепту іспанським та украӥнським народами, зумовлені відмінним світосприйняттям, менталітетом, історико-культурними та соціально-політичними чинниками, а також розбіжностями у мовній свідомості представників цих народів.

У прочесі дослідження було встановлено, щз універсальні характеристики концепту НЕЗАЛЕЖНІСТЬ під виливом переважно позамовних чинників набули специфічних рис в украӥнській та іспанській лінгвокультурах, що особливо яскраво прослідковується у відмінних конотаціях мовних одинииь-вербалізаторів кониепту. Встановлено, що ядерний елемент концепту НЕЗАЛЕЖНІСТЬ у мовній картині світу Іспанії має більш особистісну природу, фокусуючись на індивіді, та менше піддається зовнішньому впливу глобалізованого суспільства, тоді як в сучасній українській лінгвокультурі він проектується насамперед на загальнонаціональне благо і асоціюється з місцем Украӥни в сучасному світі. Репрезентація негативних когнітивних знак досліджуваного концепту в іспанській мові базується на лексемах, що мають спільну основу з ядром-вербалізатором концепту (independencia - independentismo), тоді як у мовній картині світу Украӥни лексеми незалежність і сепаратизм екстраполюються, будучи антонімами.

Ключові слова: культурно маркований конщепт, конщептуальна сфера, мовна картина світу, поняттевий, асоиіативний, аксіологічний складник, конотація. 